\title{
Approaches to the development of cognitive process dimensions in financial literacy: an empirical study
}

\author{
Kateřina Berková \\ Faculty of Finance and Accounting, University of Economics, Prague \\ Crech Republic \\ Email: katerina.berkova@vse.cr. \\ Pavel Krpálek \\ University College of Business in Prague, \\ Crech Republic \\ Email:krpalek@vso-praha.eu
}

\begin{abstract}
The article explores various approaches to the development of cognitive process dimensions in financial literacy. It is based on the empirical research of the financial literacy levels among 1,207 fifteen-year-old Czech students compared with 18 countries worldwide (OECD, 2014a). Applying the regression model, the study has examined the strength of the relationship between the actual financial competence of 284 Czech students aged 17-18, studying economic disciplines, and their school performance. The research has produced the following conclusions: (a) a weak dependence of actual skills on school performance; (b) inherently associated consequence of school performance is not corresponding to the actual financial skills; (c) a low level of financial competence in the dimensions - Remember, Understand and Apply. Proceeding from the research results, it will be desirable to focus on the transfer of economic methods and foreign practice into the learning process, thereby contributing to the improvement of the current situation in Czech Republic.
\end{abstract}

Keywords: economics, financial literacy, cognitive process dimension, Programme for International Student Assessment.

JEL Classification: A12, A20, B0

\section{INTRODUCTION}

Development of financial literacy with the emphasis on creativity is currently an important topic, being pursued by a number of researchers and teachers aiming to achieve desirable level of economic education among their students (Ebrahimi \& Jahnian, 2014; Puryeas, 2016; Lucas, 2016). There are several reasons for the above trend; nevertheless, the most significant cause is the ever-increasing likelihood of young people facing higher financial risks, due to more frequent breakdowns of socioeconomic systems worldwide. This phenomenon is caused by increased life expectancy, reduced prosperity, uncertain economic situation 
overall and thus, greater responsibility for many economic decisions. Individuals may face the necessity of making their own financial decisions while choosing their future education and its financing at a relatively young age (about 15-16 years old) (OECD, 2014a). In order to increase the level of financial literacy among young people in particular, there has been an increase in the number of countries participating in PISA (Programme for International Student Assessment), implemented by the OECD within the context of its research activities at all continents worldwide. It sets out to measure the level of financial literacy among fifteen-yearold pupils who are in their final year of compulsory education (Česká školní inspekce/Czech School Inspection, 2016). Czech Republic also participates in the PISA programme and through its National Strategy it created a financial educational system seeking to increase the level of financial literacy among the citizens of Czech Republic, reflecting the changing demand of the financial market development and the learning needs of the students.

The objective of this research study is to determine the strength of the relationship between the actual financial competencies of 284 17-18-year-old Czech students studying economic disciplines and their current school performance. Based on the regression model, this analysis will prove or disprove the existence of the relationship between success at school and the actual skill defined by the cognitive dimensions - Remember, Understand and Apply. In other words, we strive to find out whether it is justified to assess the level of financial literacy among students by applying the criterion of the acquired school assessment grading, which is a popular aspect of the Czech educational system. This finding is conditional upon proving the instability of the relationship between the variables, which was significantly verified in several independent foreign studies (Little et al., 2003; Kiliyanni \& Sivaraman, 2016). Otherwise, it will be obvious that the level of financial literacy can be significantly strengthened by work experience, a cognitive approach to learning, age and other factors, as it was substantiated by foreign studies. For the reason of the defined size, the article does not focus on proving all of the major factors affecting the level of financial literacy in the study sample.

\section{LITERATURE REVIEW}

Measuring of the level of financial literacy among students under the PISA 2012 international survey (OECD, 2014a) focuses on four content categories (1 - Money and Transactions; 2 - Planning and Management of Finances; 3 - Risk and Reward; 4 - Financial Landscape). A total of 18 countries worldwide took part in the survey, with 288 schools, i.e. 1,207 students, participating in the Czech Republic. Czech pupils ranked among the 6 countries with above-average results (the others were Belgium, Estonia, Australia, New Zealand and the Municipality of Shanghai). For our research study Category No. 2 is of key importance as it is relates to the issue of asset and capital structure management, cash flow management and finding ways to improve one's own financial situation.

As to the level of financial literacy Czech students recorded above-average results in international OECD comparison, thus placing the CR among the most successful countries. Results of Czech pupils are statistically comparable with the results of those from New Zealand and Poland. Statistically significant results falling below the average of the OECD countries were achieved by pupils from the USA, Russian Federation, France, Slovenia, Spain, Croatia, Israel, Slovakia, Italy and Colombia (listed in descending order). Czech pupils manage to analyze and make decisions in ordinary financial situations, but as of yet they are not equipped with the exact ability to analyze complex, not totally clear financial products and financial situations in the long term (OECD, 2014a).

Despite the favourable results in the Czech Republic, it is necessary to systematically develop financial literacy in students and also search for factors, which can be used to prove the given level of literacy. 
According to the OECD, there is an identifiable relationship between mathematical and financial literacy. In most countries, students with high levels of mathematical literacy tend to achieve a high level of financial literacy (the largest representation is seen in the Czech Republic and Spain). The level of financial literacy is significantly influenced by a combination of demographic and socio-economic factors, such as the cultural background of the family, occupation of the parents, size of the town where the school is located (OECD, 2014b; Štúr, Krpálek \& Krpálková Krelová, 2013). Kiliyanni \& Sivaraman (2016) examined the factors affecting the level of financial literacy in India. In a sample of 736 young people from Kerala (i.e. the most literate state in India) they managed to prove that the level of financial literacy was significantly influenced by gender, marital status, age, religion, education, occupation, work experience, income and education of parents and above all, discipline and a cognitive approach to learning, which is in line with the OECD research results (2014). The formation of students' cognitive approach to studying economic subjects is affected particularly by the intellectual level of students and the facilitator of the learning process (teacher). Proceeding from the conditions of economic discipline study programmes, several of our published studies produced results showing a much stronger influence of the competence of the learning process facilitator (i.e. presentation of topics, communication skills, the ability to explain and encourage students to think) on the school performance. As to this competence it has been statistically proven that it has a stronger impact on financial literacy than the intellectual level of the student. Concurrently, this competence has demonstrated a motivational potential (Berková \& Krejčová, 2016). Therefore, proceeding from the existing research on the international and national levels, a learning process facilitator can be considered as a major link determining school performance.

However, referring solely to student achievements as a way of identifying their cognitive skills does not provide a correct informational value, because the school performance reflects nothing other than the student's readiness on a given topic at a given time. Another important question arises in this connection: Are the school performance of a student and his/ her actual cognitive skills consistent? The importance of this question is substantiated when recapitulating several studies of Czech and foreign researchers. This relationship was examined with a positive result by Stránská, Poledňáková (2005) in Czech pupils of primary and secondary schools focusing on general intellectual skills. Little et al. (2003) were investigating a causal relationship between the actual intellective (cognitive) skills and academic achievements of students in Japan, the USA and Germany, measured using the Raven's Progressive Matrices method, based on an intelligence test. A very low correlation between the school performance of students and their intellective (actual) skills is typical for US students. On the other hand a strong causal relationship has been identified in Japan and Germany. School performance and the actual cognitive skills of students are not always consistent and the relationship between school performance and the actual skills of students is not always provably strong.

Referring to the research work of the foreign scientists Kiliyanni \& Sivaraman (2016) and our previous empirical studies, the weak correlation relationship between the actual cognitive skills of students and school performance is caused by the influence of the learning process facilitator and his/her method of encouraging students to search for deeper understanding. Students with better academic achievements often lack a deepthought process, are unable to search for links, connections or structures and join them into a single whole compared to those students whose school performance is weak. The reason for this situation is the prevailing surface style of learning that develops only the basic dimension of the cognitive process - the level of learning information by rote and its subsequent reproduction (Taylor \& Klein, 1998). This phenomenon can be gradually eliminated by devoting greater care to the development of creative thinking through epistemological processes and methods used in economic science.

The application of procedures aimed at developing creative thinking in economic science and education is facilitated by the conceptual model of the Higher-Order Cognitive Skills (HOCS) that represents the 
epistemological process of thinking development in science, technology, environment, society, economy and policy (STESEP) education, as well as activity and creativity development (Zoller, 2015, p. 4476). By applying this model it is possible to create higher-order cognitive skills - question asking, system-, critical-and evaluative thinking, problem solving, decision making as well as moral thinking, creative thinking and transfer. The model is very closely connected with the revised Bloom's taxonomy of cognitive dimensions (Anderson et al., 2001), which is its predecessor and allows identification of 6 dimensions of cognitive process (learning objective), i.e. Remember, Understand, Apply, Analyze, Evaluate and Create. According to Tetteh \& Sarpong (2015), for the positive development of the student achievements it is optimal to use an active learning strategy. By applying this strategy we develop in students the highest Knowledge Dimension - Metacognitive Knowledge and the highest Cognitive Process Dimension - Creativity. This issue concentrating on the increase in creativity and innovation in the context of development of education for entrepreneurship has been examined by Krpálek \& Krpálková Krelová (2016). Proceeding from empirical research the authors present recommendations for development of education for entrepreneurship focusing on creativity and innovation at all levels of education and vocational training. Bernat et al. (2009) dealt with students' entrepreneurship skills at the universities in six selected post-socialist countries, namely Lithuania, Latvia, Poland, Ukraine, Russia, and Hungary. Belas et al. (2016) proposed to create more room for increased use of modern teaching methods in order to improve application skills of students. In this context, it is necessary to focus on the use of modern methods that promote creativity and initiative of students (case studies, problems solution method and brainstorming). The current method of teaching traditionally focused on gaining of encyclopaedic knowledge, that can be more use full in the knowledge competition, than the real life.

Creative thinking holds an important position in economic education. It is one of the prerequisites guaranteeing the effective and sustainable acquisition of new knowledge and its subsequent deepening with full comprehension. This idea is at the centre of attention of the Indonesian teacher and researcher Subroto (2015), who examined cognitive approaches to development of creative thinking in students of economic disciplines. His research confirmed that the higher professional specialisation of students could be ensured through the development of creative thinking. The acquisition of deeper and meaningful sustainable knowledge can be achieved by reviewing the economic educational content which will be presented with the help of such strategies that will lead to the development of creative thinking (Zoller, 2015).

In the economic interpretation of phenomena, one may apply the general economic methodology. Based on their significance, Jurečka et al. (2013, p. 25) includes, among the methods used in economics, (a) abstraction allowing differentiation between essential and unimportant elements and preparation of the object of research for analysis; (b) analysis; (c) synthesis; (d) induction; (e) deduction; (f) modelling; (g) observation of economic reality; $(\mathrm{h})$ experiment enabling studying the phenomena of the real world under supervised and controlled conditions. These methods play an important part in the development of cognitive dimensions in relation to thinking. In this way it is subsequently possible to achieve singular dimensions of cognitive processes in individuals up to the level of creative thinking.

The links among economics, thinking and the deduction of correct conclusions were commented on by the prominent English economist J. M. Keynes: "Economics is an apparatus of the mind, a technique of thinking which helps its possessor to draw correct conclusions" (in Jurečka et al., 2013, p. 19). Therefore, it can be noted that the properly selected strategy influences school performance. The same conclusions were arrived at by Eren \& Coskun (2016); Cheung \& Jhaveri (2016). 


\section{METHODOLOGY}

\subsection{Theoretical concept}

The theoretical foundation of the research is the revised version of Bloom's two-dimensional taxonomy (Anderson et al., 2001), defining cognitive processes according to their difficulty. The original and revised Bloom's taxonomy in the conditions of Czech economic education is dealt with by Krpálek \& Krpálková Krelová (2012). The cognitive process dimensions, considered relevant for this research study, are defined as follows (Anderson et al., 2001, p. 31):

1. Remember (Retrieve relevant knowledge from long-term memory; typical verbs are identify, define, add, label, specify, visualize);

2. Understand (Construct meaning from instructional messages, including oral, written, and graphic communication; typical verbs are explain, seek, interpret, calculate, summarize);

3. Apply (Carry out or use a procedure in a given situation; typical verbs are apply, demonstrate, discuss, explain, show);

4. Analyze (Break material into constituent parts and determine how the parts relate to one another and to an overall structure or purpose; typical verbs are find the principle of arrangement, split into sub-elements, decide, explain relationships, find a solution);

5. Evaluate (Make judgments based on criteria and standards; typical verbs are to argue, defend, oppose, support opinions, give critique, judge, assess, justify);

6. Create (Put elements together to form a coherent or functional whole, reorganize elements into a new pattern or structure; typical verbs are categorize, combine, modify, suggest, summarize, draw conclusions, organize, reorganize).

\subsection{Objective, hypotheses}

The objective of the research is to determine the causal relationship between the school performance of 17-18 year-old students and their actual cognitive skills relating to financial issues and on this basis to propose a methodology for the development of the cognitive process dimensions. The research task focuses on the cognitive dimensions - Remember, Understand and Apply. Higher-order cognitive dimensions are not included, as they were not being developed in these students in the course of the learning process. Yet the recommendations also pay attention to the methodology for higher-order dimension development, for the ability to analyze, solve problems of financial matters on a short term basis and draw correct conclusions while engaging the creative thinking of an individual was identified by the OECD survey (2014a).

The hypotheses below are to be tested in relation to the objective, namely:

- Hypothesis 1: The level of cognitive dimension - Remember depends on study performance.

- Hypothesis 2: The level of cognitive dimension - Understand depends on study performance.

- Hypothesis 3: The level of cognitive dimension - Apply depends on study performance.

\subsection{Participants}

The research carried out in 2016 was participated in by 284 students aged $17-18$, studying economic disciplines, specialising primarily in economics and accounting (46\% of the sample was formed by individuals of 17 years of age and $54 \%$ by those of 18 years of age). The study sample was formed on the basis of intentional sampling and was made up of students whose financial skills had been developed by various cognitive approaches. Moreover, the selection of the study sample was conditioned by the 
possibilities of gaining work or practical experience during the studies. The age range selection aimed at identifying the level of financial literacy of older students who study the actual economic subjects and establishing whether the school performance is a factor strong enough to determine their actual cognitive skills in the economic-financial area.

Cognitive skills of students were monitored according to their academic grading in the Accounting Subject (see Table 1). The subject in question was selected as it provides possibilities of assessing the integrated economic knowledge and skills within a single closed unit. Students with lower academic results appear in greater numbers (Grades 3-5 on the assessment scale represent 62.4\%, while Grades 1-2 account for $37.6 \%)$.

Table 1

Structure of respondents according to school performance in the Accounting Subject

\begin{tabular}{|l|c|c|}
\hline \multicolumn{1}{|c|}{ Grade } & Absolute frequency & Relative frequency \\
\hline $1-$ Excellent & 34 & $11.9 \%$ \\
\hline $2-$ Very Good & 73 & $25.7 \%$ \\
\hline $3-$ Good & 86 & $30.3 \%$ \\
\hline $4-$ Sufficient & 82 & $28.9 \%$ \\
\hline $5-$ Insufficient & 9 & $3.2 \%$ \\
\hline Total & 284 & $100 \%$ \\
\hline
\end{tabular}

Source: Authors' results.

\subsection{Data}

The data were collected applying the method of achievement tests, which identified the actual level of the financial skills of students on the level of individual cognitive process dimensions. Students were to show their specialist knowledge and skills of the financial (economic - accounting) issues that covered the extent of topics taught so far. Stretching over two teaching units, the achievement test was to check (a) the Remember dimension via a set of theoretical questions; (b) the Understand dimension by way of solving practical economic situations; (c) the Apply dimension, again by way of solving practical economic situations with greater emphasis placed on the ability of abstraction, deduction and induction. (The content of the examined dimensions and number of tasks within the individual dimensions are listed in Table 2; each issue is identified by a number.) Questions and numerical problem-solving tasks were assigned in a way other than the students were used to from their lessons in order to establish whether the students were able to depart from the common procedures taught, whether they were able to use deduction and place elements in context and in an integral whole while engaging logical, abstract thinking in the financial sphere.

As to their content, achievement tests correspond to Category Two of the PISA 2012 Survey (OECD, 2014a) aimed at measuring the level of financial literacy. (Let us mention once again that Category Two deals with the issues of asset and capital structure management, cash flow management and finding ways to improve one's own financial situation.)

The independent variable is the school performance (academic grade) in the Accounting Subject. The dependent quantitative variable is the real financial skill found through the point score that students have gained as an aggregate of both tests. The purpose of these variables' direction is to find out if a level of financial literacy can be explained by a grade. In other words if school requirements form students' financial skills expressed by the grades, and it is therefore desirable to consider the classification of those skills that represent a recognized OECD framework. Thus, a grade was chosen as an independent variable in a simple regression model, and the real financial skill was chosen as the dependent variable. 
Content of tasks and their number in individual cognitive process dimensions

\begin{tabular}{|l|c|l|}
\hline $\begin{array}{c}\text { Cognitive Process } \\
\text { Dimension }\end{array}$ & $\begin{array}{c}\text { Number } \\
\text { of tasks }\end{array}$ & \multicolumn{1}{|c|}{ Number of areas covered in the tasks } \\
\hline Remember & 11 & $\begin{array}{l}\text { (1) Entrepreneurship; (2) Ownership and capital structure; (3) Balance Sheet; } \\
\text { (4) Valuation of assets; (5) Tax system; (6) Legal system of the CR; (7) } \\
\text { European Union; }\end{array}$ \\
\hline Understand & 13 & $\begin{array}{l}\text { (8) Money and financial markets; (9) Accrued and deferred costs and } \\
\text { revenues, (10) Accrual principle, (11) Balance Sheet; (12) Real-life accounting } \\
\text { cases and their impact on the accounting books; (13) Determination of } \\
\text { production capacity; (14) Relationship between a company and a revenue } \\
\text { authority in terms of value added tax; (15) Charging interest; }\end{array}$ \\
\hline Apply & $\begin{array}{l}\text { (16) Value added tax in a retail chain; (17) Fixed and variable costs and price } \\
\text { calculation; (18) Application of the accrual principle for the accrued and } \\
\text { deferred costs and revenues with the impact on the profit or loss in different } \\
\text { periods; (19) Financial evaluation of the situation and company performance } \\
\text { efficiency as depicted by accounting reports. }\end{array}$ \\
\hline
\end{tabular}

Source: Authors' results.

The points scored were transferred to a relative value due to the fact that the maximum number of points students were able to acquire in both tests was different (38 points and 39 points) and, therefore, it was necessary to ensure a relative comparability of the student performance. In order to verify the hypotheses the points scored by students are examined in detail in relation to the cognitive process dimensions analyzed in this study. The data processed in this way will be used to establish causality between school performance and the level of cognitive skills of students. The points scored will further be analyzed in the sub-groups of students according to their school performance (academic grading) applying relevant methods of descriptive statistics with the aim of identifying the reversed trend between school performance and the actual cognitive skills of students. For these purposes the summarised results acquired from the measurement of the cognitive skill level have been converted to assessment grades applying the standardized rules used in the Czech schooling system.

\subsection{Methodological design}

The data were analyzed with the support of the NCSS statistical software (2007 version) on the basis of mathematical statistical methods. Testing of null hypotheses was carried out at a $5 \%$ level of significance using the linear regression model through a regression t-test of parameters and an F-test of the model. The linear regression model was chosen both for the satisfactory character of the variables and for revealing of the unilateral dependence of the variables, when the independent variable - explanatory variable (grade) stands against the dependent one - explained variable (real financial skills). For the reason of demonstration, if school requirements form financial skills (consequence) in the form of grades (cause), other control variables (gender control, residence, socio-economic background) were not included in the model.

For the purpose of testing the hypotheses applying the mathematical statistical methods, the null hypothesis claims that there is no dependence between the variables. The null hypotheses and alternative hypotheses have been formulated as follows:

$H_{0-1}: \beta i=0$

The level of the cognitive dimension - Remember is not dependant on school performance. 


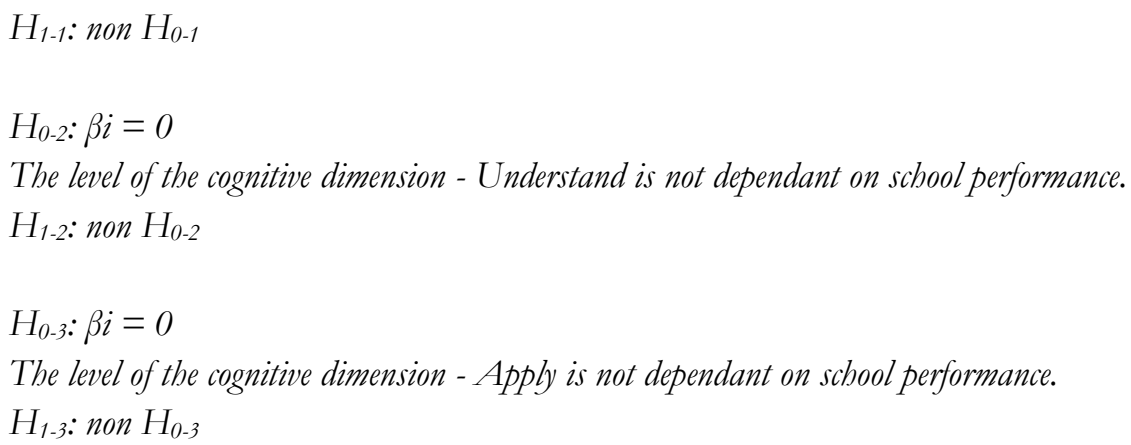

The normality of the quantitative data was checked with several statistical tests that verify the assumption of a normal distribution of data (Shapiro Wilk, Anderson Darling, D'Agostino Skewness, D'Agostino Kurtosis, D'Agostino Omnibus). The reliability of the test increases with the quantity of the measurements $(n>100)$. Our research complies with this condition. The distribution of the data was further checked by the Exploratory Data Analysis (Probability Plots). A linear regression model was set up for the rejection or non rejection of the null hypotheses with a significance level $\alpha=5 \%$. The null hypothesis will be rejected if $a>P$-V alue. Applying the method of least squares, regression coefficients (parameters) $b_{0}$ and $b_{1}$ will be estimated, where $b_{0}$ represents a constant (Y-intercept) and $b_{1}$ denotes the average change in the dependent variable $y$ for a 1 -unit change in the independent variable $x$. In this way it is possible to determine the strongest or weakest dependence of the dependent variable on the independent variable as well as positive linear relationship (+) or negative linear relationship (-). The value of the correlation coefficient $R^{2}$ is taken into consideration in the model as it denotes the strength of the relationship.

The application of the linear regression analysis provides the quantification of the dependence of the variable $y$ (the points scored corresponding to the level of actual financial skills) on the independent variable $x$ that denotes school performance in the Accounting Subject.

On the basis of a sample comprising 284 observations an estimate of an empirical function will be made using the following parameters. In mathematical terms, the linear regression model can be written as the equation below (Draper \& Smith, 1998; Weiss, 2012):

$$
Y=f\left(x ; b_{0}, b_{1}\right)
$$

where: $b_{0}$ is a constant, $b_{1}$ is the estimate of the theoretical regression coefficient $\beta_{1}$.

The estimate of the theoretical regression function, which is in the form of a regression line, can be expressed as:

$$
Y_{i}=b_{0}+b_{1} x_{i}
$$

provided that the assumptions of the classical linear model are met.

\section{EMPIRICAL RESULTS}

The level of the financial competence of Czech students aged 17-18 is considerably low. The average points scored converted to a success rate in the test come to $48.2 \%$. Weak performances have been recorded at the level of remembering and applying the theory in specific economic situations. (In the dimension - 
Remember the score amounts to $51 \%$; in the dimension - Understand to $57.9 \%$ and in the dimension Apply to $25.7 \%$.) Students have difficulty using economic methods such as abstraction, deduction and induction. Even the lowest ability of mere memorization (remembering) of the acquired knowledge is at a poor level. The students have the best grasp of the issues relating to entrepreneurship, recording real-life cases in accounting books, the tax system with an emphasis on determining the relationship with the revenue authority in terms of value added tax in a retail chain, the Czech system of law, and they are able to understand the accrual principle. As to other researched areas, (see Table 2), the students have shown significant inadequacies. They are very weak in their ability to apply specialist theoretical knowledge in solving specific economic situations.

\subsection{Relationship between school performance and actual cognitive skills}

The school performance assessed on the basis of the six-month school activities of students is compared with the actual performance (points scored) within an individual cognitive dimension established in real time. Performance in the achievement test by students divided according to their academic grading was converted to assessment grades applying the standardized rules used in the Czech schooling system. This comparison identified the reversed trend between school performance and the actual skill determined by the cognitive process dimension (see Table 3).

Table 3

School performance results (academic grading) versus the actual performance in the individual cognitive dimension

\begin{tabular}{|c|c|c|c|c|c|}
\hline $\begin{array}{l}\text { Academic grading in } \\
\text { the given subject }\end{array}$ & $\begin{array}{l}\text { Performance } \\
\text { in the } \\
\text { dimension - } \\
\text { Remember }\end{array}$ & $\begin{array}{l}\text { Performance } \\
\text { in the } \\
\text { dimension - } \\
\text { Understand }\end{array}$ & $\begin{array}{l}\text { Performance } \\
\text { in the } \\
\text { dimension - } \\
\text { Apply }\end{array}$ & $\begin{array}{l}\text { Performance } \\
\text { in all } \\
\text { dimensions }\end{array}$ & $\begin{array}{l}\text { Academic } \\
\text { grading } \\
\text { reflecting the } \\
\text { actual skill }\end{array}$ \\
\hline $1<1-0.9>$ & 0.565 & 0.692 & 0.408 & 0.555 & 4 \\
\hline $2<0.89-0.75>$ & 0.522 & 0.618 & 0.280 & 0.473 & 5 \\
\hline $3<0.74-0.6>$ & 0.532 & 0.577 & 0.242 & 0.450 & 5 \\
\hline $4<0.59-0.5>$ & 0.455 & 0.509 & 0.202 & 0.389 & 5 \\
\hline $5<0.49-0>$ & 0.481 & 0.513 & 0.141 & 0.378 & 5 \\
\hline
\end{tabular}

Source: Authors' results.

The achievement test included exercises with the actual tasks worded in a way other than the students were used to from their lessons in order to establish whether the students were able to depart from the common procedures taught and to what degree they were able to make use of abstract-visual and financial thinking. The results suggest a significant reversed trend between school performance in the Accounting Subject and the actual cognitive skills of students assessed in the Accounting Subject with the grades 1Excellent and 2-Very Good. According to the evaluation of cognitive skills these students go down by 3 to 4 grades in real terms. Cognitive skills of students with a worse school performance (grades 3-Good to 5Insufficient) correspond more to their school achievements in the given subject. However, it should be noted that there was a marginal number of students placed under the grades 3-Good to 5-Insufficient with test scores which would corresponded to the score of an excellent student. Nonetheless, with the $5 \%$ level of significance this relationship has not been statistically proven. 


\subsection{Normality of data}

The normality of the data (see Table 4) was analyzed at a 5\% level of significance, but it was verified only by one (D'Agostino Kurtosis test) out of the total of five used tests (the others being Shapiro Wilk, Anderson Darling, D'Agostino Skewness, D'Agostino Omnibus).

Table 4

Normality of the analyzed data

\begin{tabular}{|l|c|c|c|}
\hline \multicolumn{1}{|c|}{ Test } & T-value & Prob Level & Reject 5\% \\
\hline Shapiro Wilk & 0.9918 & $\mathbf{0 . 1 1 5 8 9 9}$ & No \\
\hline Anderson Darling & 0.6545 & $\mathbf{0 . 0 8 7 6 2 1}$ & No \\
\hline D'Agostino Skewness & -1.7732 & $\mathbf{0 . 0 7 6 1 9 0}$ & No \\
\hline D'Agostino Kurtosis & 0.9840 & $\mathbf{0 . 3 2 5 0 9 4}$ & Yes \\
\hline D'Agostino Omnibus & 4.1127 & $\mathbf{0 . 1 2 7 9 2 0}$ & No \\
\hline
\end{tabular}

Source: Authors with the help of the NCSS program (version 2007).

The data distribution was tested with the Exploratory Analysis that ascertained the level at which the distribution of the sample data approaches the normal distribution. The Exploratory Analysis (see Figure 1) has verified that the data have not departed too far from the straight line (in the middle), which can be considered a borderline result. In conclusion it can be stated that the input data are correct for a subsequent analysis.

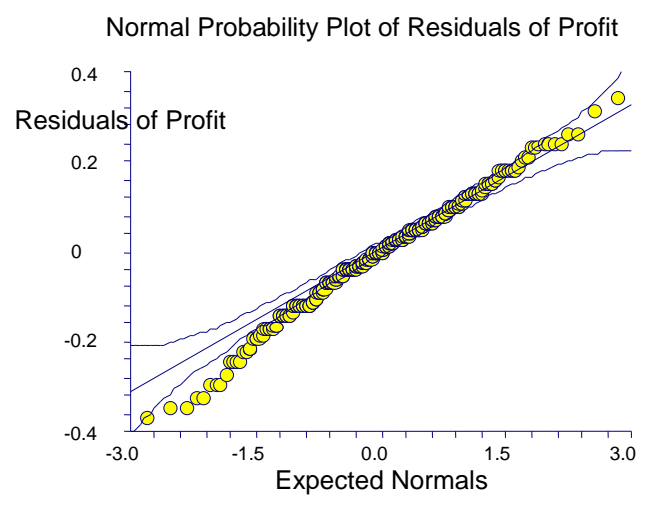

Figure 1. Exploratory Analysis

Source: Authors with the help of the NCSS program (version 2007).

\subsection{Linear regression analysis $\mathbf{H}_{0-1}-\mathbf{H}_{0-3}$}

The method of linear regression analysis has been applied to test the influence of the school performance on the level of cognitive process dimensions (Remember, Understand, and Apply). In the interpretation of the regression model, it should be kept in mind that increasing the grade in the form of an increase in the quantitative variable (1-5) actually means worsening (decrease) in school results and decreasing of the grade in the form of a decrease of the quantitative variable (1-5) means improvement (increase) of school results in the model. Therefore, based on this logic, the results of all three regressions 
are interpreted. For each relationship a regression model was set up and the regression coefficients were evaluated (see Figure 2, Table 5).

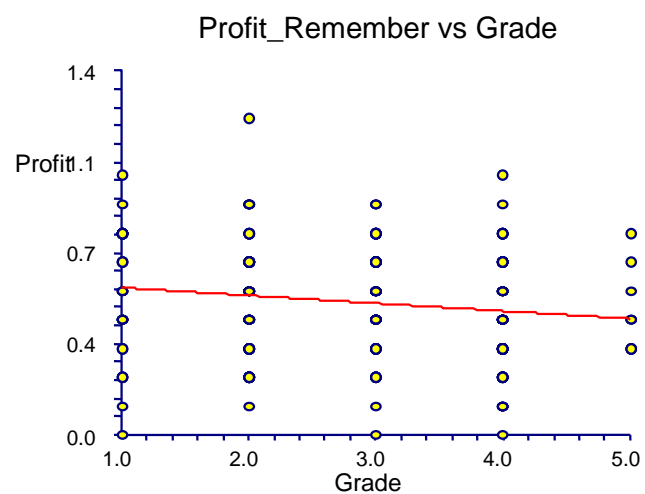

Figure 2. Linear Regression Plot Section $\mathbf{H}_{0-1}$

Source: Authors with the help of the NCSS program (version 2007).

Table 5

Linear Regression $\mathrm{H}_{0-1}$

\begin{tabular}{|l|c|c|c|c|c|}
\hline \multicolumn{1}{|c|}{ Variables } & $\begin{array}{c}\text { Regression } \\
\text { Coefficient } \mathbf{b}_{\mathbf{i}}\end{array}$ & $\begin{array}{c}\text { Standard Error } \\
\mathbf{S b}_{\mathbf{i}}\end{array}$ & T-Value & $\begin{array}{c}\text { Prob } \\
\text { Level }\end{array}$ & $\begin{array}{c}\text { Reject } \mathbf{H}_{\mathbf{0}} \\
\text { at } \mathbf{5} \text { \% }\end{array}$ \\
\hline Intercept $b_{0}$ & 0.5956 & 0.0342 & 17.4031 & $\mathbf{0 . 0 0 0 0}$ & Yes \\
\hline Grade $b_{1}$ & $\mathbf{- 0 . 0 3 0 1}$ & 0.0112 & -2.6770 & $\mathbf{0 . 0 0 7 9}$ & Yes \\
\hline
\end{tabular}

Source: Authors with the help of the NCSS program (version 2007).

With 95\% test reliability, one may argue that there is a negative relationship between the dimension based on remembering financial issues and school performance $(\mathrm{P}=0.0079)$. The regression model of the linear relationship can be written for $\mathrm{n}=284$ as follows:

$$
Y_{i}=0.5956-0.0301 x_{i}
$$

If the grade increases by 1 unit (i.e. if the school results get worse), the score describing the level of financial skills in the dimension Remember decreases by an average of 0.03 points.

Verification of the $\mathrm{H}_{0-2}$ is illustrated in Table 6 and Figure 3.

Table 6

Linear Regression $\mathrm{H}_{0-2}$

\begin{tabular}{|l|c|c|c|c|c|}
\hline \multicolumn{1}{|c|}{ Variables } & $\begin{array}{c}\text { Regression } \\
\text { Coefficient } \mathbf{b}_{\mathbf{i}}\end{array}$ & $\begin{array}{c}\text { Standard Error } \\
\mathbf{S b}_{\mathbf{i}}\end{array}$ & T-Value & $\begin{array}{c}\text { Prob } \\
\text { Level }\end{array}$ & $\begin{array}{c}\text { Reject } \mathbf{H}_{\mathbf{0}} \\
\text { at 5 \% }\end{array}$ \\
\hline Intercept $b_{0}$ & 0.7344 & 0.0295 & 24.9205 & $\mathbf{0 . 0 0 0 0}$ & Yes \\
\hline Grade $b_{1}$ & -0.0542 & 0.0097 & -5.6094 & $\mathbf{0 . 0 0 0 0}$ & Yes \\
\hline
\end{tabular}

Source: Authors with the help of the NCSS program (version 2007). 


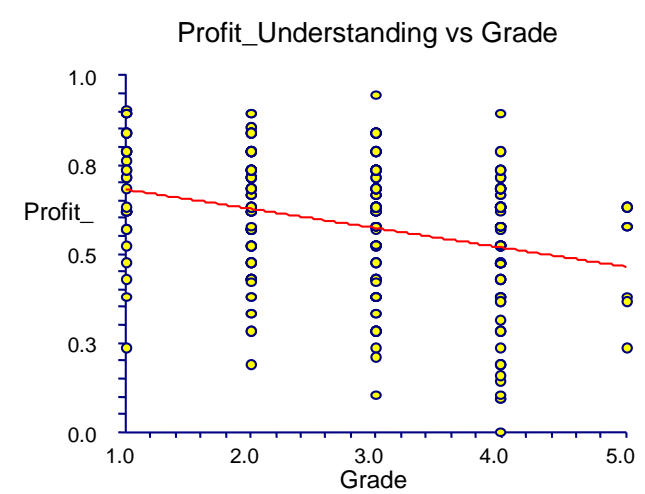

Figure 3. Linear Regression Plot Section $\mathbf{H}_{0-2}$

Source: Authors with the help of the NCSS program (version 2007).

With $95 \%$ test reliability, one may argue that there is a negative relationship between the dimension based on understanding and school performance $(\mathrm{P}<0.01)$. The regression model of the linear relationship can be written for $\mathrm{n}=284$ as follows:

$$
Y_{i}=0.7344-0.0542 x_{i}
$$

If the grade increases by 1 unit (i.e. if the school results get worse), the score describing the level of financial skills in the dimension Understand decreases by an average of 0.054 points.

Verification of the $\mathrm{H}_{0-3}$ is illustrated in Table 7 and Figure 4.

Table 7

Linear Regression $\mathrm{H}_{0-3}$

\begin{tabular}{|l|c|c|c|c|c|}
\hline \multicolumn{1}{|c|}{ Variables } & $\begin{array}{c}\text { Regression } \\
\text { Coefficient } \mathbf{b}_{\mathbf{i}}\end{array}$ & $\begin{array}{c}\text { Standard Error } \\
\mathbf{S b}_{\mathbf{i}}\end{array}$ & T-Value & $\begin{array}{c}\text { Prob } \\
\text { Level }\end{array}$ & $\begin{array}{c}\text { Reject } \mathbf{H}_{\mathbf{0}} \\
\text { at } \mathbf{5} \text { \% }\end{array}$ \\
\hline Intercept $b_{0}$ & 0.4220 & 0.0368 & 11.4794 & $\mathbf{0 . 0 0 0 0}$ & Yes \\
\hline Grade $b_{1}$ & -0.0578 & 0.0121 & -4.7900 & $\mathbf{0 . 0 0 0 0}$ & Yes \\
\hline
\end{tabular}

Source: Authors with the help of the NCSS program (version 2007).

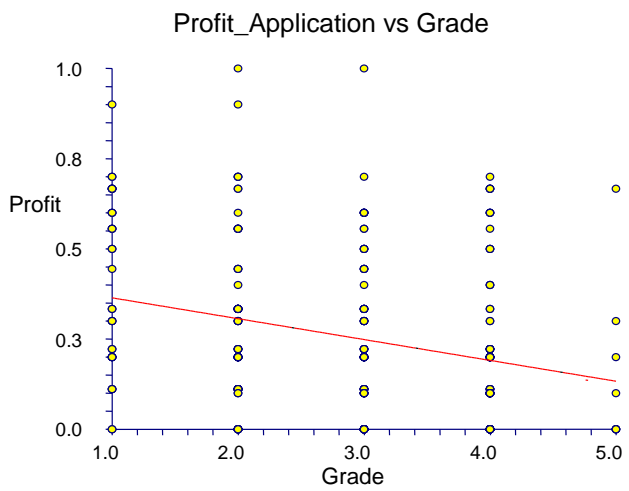

Figure 4. Linear Regression Plot Section $\mathbf{H}_{0-3}$

Source: Authors with the help of the NCSS program (version 2007). 
With 95\% test reliability, one may argue that there is a negative relationship between the dimension based on application and school performance $(\mathrm{P}<0.01)$. The regression model of the linear relationship can be written for $\mathrm{n}=284$ as follows:

$$
Y_{i}=0.4220-0.0578 x_{i}
$$

If the grade increases by 1 unit (i.e. if the school results get worse), the score describing the level of financial skills in the dimension Apply decreases by an average of 0.058 points.

\section{It may be concluded that at the $5 \%$ level of significance we reject $\mathrm{H}_{0-1} ; \mathrm{H}_{0-2} ; \mathrm{H}_{0-3}$.}

\section{DISCUSSION}

Research has proven that requirements placed on students in the form of grades affect real financial skills and thus determine students' financial literacy. However, the values of the partial regression coefficients are low despite the proven dependence.

The school performance of the students is evidently influenced by other important factors, which have not been included in the model but which have been substantiated by our previous research activities (Berková \& Krejčová, 2016) and which are mentioned by other empirical studies as well (Kiliyanni \& Sivaraman, 2016; OECD, 2014b; Štúr, Krpálek \& Krpálková Krelová, 2013). These include the cognitive approach of the learning process facilitator as well as students' work and practical experience that support the learning of the theory and its transferability into real-life situations in a more efficient manner. However, their analysis is not the objective of this article, but considerable attention will be paid to them in the forthcoming research. One must note that the school performance has a greater influence on the dimension - Apply than on Understand and Remember. Nevertheless, these differences are marginal and insignificant.

In the development of financial literacy, logical thinking is the lynchpin for the functioning of cognitive processes in learning. It can be quite easily developed in mathematical disciplines that are the basis for economic science. This can be achieved proceeding from the proven relationship between mathematical and financial literacy, which was verified mostly in Czech and Spanish individuals (OECD, 2014a). Therefore, it is desirable that mathematical abilities are more supported in this study group of 17-18 yearold Czech students. Thanks to the mathematical competence, students will be able to use higher levels of epistemological processes in economic science, strongly determined by the methods of abstraction, analysis, synthesis, induction and deduction (Jurečka et al., 2013). In order to move the cognitive process towards the higher orders of its dimensions (Analyze, Evaluate, Create) the presence of economic methods in education is desirable. This fact was known even by J. M. Keynes, who perceived economics as an apparatus of the mind helping us to draw correct conclusions, relevant in relation to the studied economic problem.

Consequently, let us take a look at the possible approaches of how the cognitive process can be moved via economic methods into its higher-order dimensions up to the level of creative, financial thinking, provided that the individual has mastered the theory with a sufficient level of understanding. At this stage, it is already possible to focus on the dimensions - Apply, Analyze, Evaluate and Create. In economic science the process of the advancement into higher orders of cognitive dimensions was very well illustrated by Zoller (2015) with his HOCS model, whose efficiency has been demonstrated by a number of indicators (a) question asking, (b) system-, critical- and evaluative thinking, (c) problem solving, (d) decision making as well as moral thinking, (e) transfer. By applying this model in practice it is possible to guarantee a higher level of actual 
financial competence in an individual. This is brought about by the option of demonstrating economic problems and their solutions directly from real-life situations. Kiliyanni \& Sivaraman (2016) established that practical experience, a cognitive approach to the study and the possibility of deeper knowledge rank among significant factors with a positive impact on the level of actual financial competence.

Nonetheless, the level of financial competence does not entirely reflect the school performance of Czech students. A similar situation has also been identified in the United States, where a very low correlation between study results and the actual ability of the student was proven (Little et al., 2003). By contrast, in Japan and Germany a very strong causal relationship was substantiated. Therefore, it is desirable to prospectively deal with the causes of the instability of the relationship between variables in different countries worldwide.

\section{CONCLUSION}

Despite the results of the PISA 2012 Survey (OECD, 2014a), showing an above-average level of financial literacy of the Czech fifteen year-old individuals in issues relating to finance, finance management, risk and reward management as well as the financial landscape, the results of this study have presented a rather sceptical view of their further development and sustainability during the study of economic disciplines with respect to students of 17-18 years of age. At the same time the school performance (i.e. the efforts of the students) is not a major factor influencing their actual financial skills, measured by various cognitive process dimensions. A weak relationship has been proven between the variables.

As the article aimed to determine the strength of the relationship between success at school and real skills, and not just to multi-dimensionally analyze the factors influencing the actual financial (cognitive) skills of individuals, the study has produced, in terms of the development of the cognitive process dimensions with the application of economic methods, the following practical conclusions that can be summarized as follows:

- The study of economic disciplines by individuals aged 17-18 in the Czech Republic does not guarantee the level of financial literacy that should correspond to such a type of study. The sustainability of the underlying assumptions and their progressive development are also not ensured.

- Inadequacies are apparent in Category No. 2 of financial literacy, i.e. in the ability to plan and manage finances with a closer focus on the asset and capital structure management, cash flow management and finding ways to improve one's own financial situation.

- The interpretation of the regression model revealed surprising relationships within the structure of the respondents, divided according to their school performance in the Accounting Subject which allows adequate development of financial competence in an integrating manner. A reverse trend in the relationship between the study performance and the actual skills has been identified, where the financial skills of students with grades 1-Excellent, reflecting not only a half-year of their work and effort, are at the actual level of the assessment grade 4-Sufficient. (Skills of grade 2-Very Good students correspond in real terms to grade 5-Insufficient.) There is a marginal group of students placed under the grades 4-Sufficient and 5-Insufficient whose actual skills match the grades 1Excellent or 2-Very Good. These relationships have revealed that it is necessary to enhance the level of student financial competence in real terms in ways other than by placing the emphasis on encyclopaedism and memorization of knowledge, which is so well-spread in the Czech Republic. 
- The proven low level of financial competence in the cognitive process dimensions of remembering, understanding and application of theory in solving practical economic situations speaks volumes about the future necessity to devote much greater attention to the tried and trusted methods of economics in the process of learning.

In an attempt to develop financial competence in higher-order dimensions of the cognitive process, it is desirable to transfer economic methods from theory to the practical application in the learning process. This will ensure a better preparedness of the young generation to survive in an every-day economic world, also thanks to the transfer of foreign practices to Czech conditions.

\section{ACKNOWLEDGEMENT}

This research was supported by the Grant Agency of Academic Alliance (Project No. GA/2016/9), the Internal Grant Agency of University of Economics, Prague (Project IGS VŠE No. F1/31/2015) and it is part of a project of Faculty of Finance and Accounting carried out with help of institutional support of VŠE (Project VŠE No. IP 100040).

\section{REFERENCES}

Anderson, L. W., \& Krathwohl, D.R. et al. (2001). A Taxonomy for Learning, Teaching and Assessing. A Revision of Bloom's Taxonomy of Educational Objectives. New York, Longman.

Belás, J., Nguyen, A., Smrčka, L., Kolembus, J., \& Cipovová, E. (2016). Financial Literacy of Secondary School Students. Case Study from the Czech Republic and Slovakia. Economics \& Sociology, 9(4), 191-206. doi:10.14254/2071-789X.2016/9-4/12.

Berková, K., \& Krejčová, K. (2016). Effect of Teachers’ Abilities on Students’ Motivation with Varying Levels of Intellectual Abilities in Economics. Journal on Efficiency and Responsibility in Education and Science, 9(3), 81-87. doi:10.7160/eriesj.2016.090304.

Bernat, T., Korpysa, J., Grundey, D., Šavriņa, B., Bilan, Y., \& Koren, A. (2009). Researching Students' Entrepreneurship Skills in Post-Socialist Countries: A Multi-Country Survey (Part 2). Transformation in Business \& Economics, 8(3), 104-130.

Česká školní inspekce. (2014). Mezinárodní šetření PISA 2012. Národní zpráva. Schopnost patnáctiletých žáků řešit problém (PISA 2012 International Survey. National Report. Ability of Fifteen Year-old Pupils to Solve a Problem), Prague, Česká školní inspekce (Czech School Inspection). Retrieved 2017-01-20 from: http://www.csicr.cz/html/PISA2012-SchResProblemy/flipviewerxpress.html/.

Draper, N.R., \& Smith, H. (1998). Applied Regression Analysis. New York, Wiley.

Ebrahimi, M., \& Jahanian, R. (2014). Strategies to increase the self-efficacy of educational administrators. International Journal of Management and Sustainability, 3(4), 250-260.

Eren, A., \& Coskun, H. (2016). Students' Level of Boredom, Boredom Coping Strategies, Epistemic Curiosity, and Graded Performance. Journal of Educational Research, 109(1), 574-588.

Cheung, C.K., \& Jhaveri, A.D. (2016). Developing Students' Critical Thinking Skills through Visual Literacy in the New Secondary School Curriculum in Hong Kong. Asia Pacific Journal of Education, 36(3), 379-389.

Jurečka, V., Hon, M., Jánošíková, I., Kolcunová, E., \& Spáčilová, L. (2013). Mikroekonomie (Microeconomics). Prague, Grada Publishing.

Kiliyanni, A.L., \& Sunitha, S. (2016). The Perception-reality Gap in Financial Literacy: Evidence from the Most Literate State in India. International Review of Economics Education, 23, 47-64.

Krpálek, P., \& Krpálková Krelová, K. (2016). Possibilities for Developing Business Potential in Economic Education. Examples of Implementation in Slovakia and the Czech Republic. Economics \& Sociology, 9(4), 119-133. doi:10.14254/2071-789X.2016/9-4/7

Krpálek, P., \& Krpálková Krelová, K. (2012). Didactics of Economic Subjects. Prague, Oeconomica. 
Little, TD., Miyashita, T., Karasawa, M., Mashima, M., Oettingen, G., Azuma, H., \& Baltes, P.B. (2003), The Links among Action-control Beliefs, Intellective Skill, and School Performance in Japanese, US, and German School Children. International Journal of Behavioral Development, 27(1), 41-48.

Lucas, B. (2016). A Five-Dimensional Model of Creativity and its Assessment in Schools. Applied Measurement in Education, 29(4), 278-290.

Ministerstvo financí (2010). Národni strategie finančního vždèlávání (National Strategy for Financial Education). Prague, Ministerstvo financí (Ministry of Finance). Retrieved 2017-01-20 from http://www.vzdelavani2020.cz/images obsah/dokumenty/knihovna-koncepci/financnivzdelavani/narodni strategie financniho vzdelavani mf2010.pdf.

OECD (2014a). PISA 2012 Results: Students and Money. Financial Literacy Skills for the 21st Century (Volume VI). PISA, OECD Publishing. Retrieved 2017-01-20 from http://www.oecd.org/pisa/keyfindings/PISA-2012-resultsvolume-vi.pdf.

OECD (2014b). The ABC of Gender Equality in Education: Aptitude, Behaviour, Confidence. PISA, OECD Publishing. Retrieved 2017-01-20 from http://www.oecd.org/pisa/keyfindings/pisa-2012-results-gender-eng.pdf.

OECD (2015). PIS A 2012 Results: Creative Problem Solving. Students'Skills in Tackling Real-life Problems (Volume V). PISA, OECD Publishing. Retrieved 2017-01-20 from http://www.oecd.org/pisa/keyfindings/PISA-2012-resultsvolume-V.pdf.

Puryear, J.S. (2016). Inside the Creative Sifter: Recognizing Metacognition in Creativity Development. Journal of Creative Behavior, 50(4), 321-332.

Stránská, Z., \& Poledňáková, I. (2005). Intellective Skills and School Successfulness of Primary and Secondary School Pupils. In 1st Conference School and Health 21 Location, Brno, 845-853.

Subroto, W.T. (2015). Creative Thinking Development to Foster Economic Creative: Evidence of State University of Surabaya. International Review of Management and Marketing, 5(3), 108-113.

Štúr, M., Krpálek, P., \& Krpálková Krelová, K. (2013). Finančná gramotnost’ na školách (Financial Literacy at Schools). In International Scientific Conference QUERE 2013, Hradec Králové, 1614-1623.

Taylor, T.L., \& Klein, R.M. (1998). On the Causes and Effects of Inhibition of Return. Psychonomic Bulletin and Review, 5, 625-643.

Tetteh, G.A., \& Sarpong, F.A. (2015). Infuence of Type of Assessment and Stress on the Learning Outcome. Journal of International Education in Business, 8(2), 125-144.

Weiss, N.A. (2012). Elementary statistics. Boston, Addison-Wesley.

Zoller, U. (2015). Research-Based Transformative Science/STEM/STES/STESEP Education for. "Sustainability Thinking" : From Teaching to "Know" to Learning to "Think". Sustainability, 7(4), 4474-4491. 